\title{
Problems and Countermeasures of Current Higher Vocational Continuing Education Development in China
}

\author{
Yiqiang Liao \\ School of Continuing Education \\ Guangdong Industry Technical College \\ Guangzhou, China 510300
}

\begin{abstract}
Vocational education or adult education is a significant part in lifelong learning system. Higher vocational colleges, as the senior form of vocational education, undertake their responsibilities of conducting pre-vocational education for cultivating technical, skillful and high-quality laborers in production, administration, construction and service, etc. and keep close connection with enterprises and other employers, especially with real economy departments so as to eventually establish a big system of vocational education and lifelong education. Currently, the common problems faced by each higher vocational academy during developing adult education include: there are less and less demands for academic education and increasing demands for non-academic education; besides, being marginalized by regular institutions for higher learning particularly by the adult education of brand-name colleges, the competition in education market becomes more intense day by day, following the prominent problem that higher vocational colleges neglect to increase inputs in adult education despite of its constantly reinforced strength of running school. Even if great progress has been achieved during developing higher vocational education by now, adult education in higher vocational colleges seemingly does not step into a steady road of development. The thesis is expected to find a sally port to provide supports for the sustainable development of adult education in higher vocational colleges by proceeding on deep researches on those realistic problems.
\end{abstract}

Keywords-vocational education; continuing education; educational reform

\section{INTRODUCTION}

Nowadays in China, with the constantly emerging of new technology and the advancement of global economic integration, in the face of competition in the industry upgrading, it has become a consensus of many enterprises that it is quite necessary to carry out continuing education and improve the whole quality of employees so as to build enterprise's core competitiveness by improving human resources and accelerate the development of enterprises. Continuing education is considered by enterprises as a dose of exciting agent under a global economic downturn and a conversion point to change the fate of enterprise economic growth. For enterprise employees, all of them have strong desires to accept continuing education in the new economic era in order to avoid being knocked out because of own obsolete intellectual skills, also for adapting to changeable requirements for their posts. Enterprises and their employees, as one of the biggest consumers for accepting the continuing education, have established and laid a strong social basis and development space for colleges and universities, especially the higher vocational and technical schools (hereinafter referred to as the higher vocational colleges) to carry out continuing education work. As institutions of imparting knowledge of practical production technology and cultivating talents with high quality, vocational colleges possess inherent advantages on carrying out higher learning or continuing education research universities orienting to front-line staff of enterprises and the advantages are that other ordinary institutions cannot compare with. So they naturally should be geared to the needs of the enterprise staff and become a vanguard of continuing education, so that to provide quality services of continuing education for enterprises.

\section{PRoblems Existing In OPENING CONTINUING EDUCATION TO ENTERPRISES' STAFF OF HIGHER VocATIONAL COLLEGES}

At the present stage, there are mainly two aspects about the vocational education carried out by higher vocational colleges to enterprises' staff: one the one hand, it includes academic education which refers to conducting higher level of academic education than staff's original education background so as to assist educatees to acquire better jobs by promoting their education level or to help them be more engaged in the current jobs, or to satisfy their demands for promoting their titles. On the other hand, it also includes on-the-job training to in-service staff and Prospective employees, which means to proceeding on various training to those employed or prospectively employed personnel for cultivating talents meeting the requirements and standards of the occupied professions and adapting to their own demands for development. However, there are still some problems existing in the aforesaid two types of continuing education forms being opened by higher vocational colleges during their teaching practice, and the exposed problems prominently reflect on the following several fields. 


\section{A. Major Setup Is Disjointed with Social Needs}

Theoretically, it is required to be forward-looking, predictive for major setting and course construction in order to provide better services and assistance for enterprises development and local economic development. As institutions of higher education which are most close to the front-line production enterprises and are able to grasp the development trend of industry and technology, higher vocational colleges should forecast and study on development trend of new technology, new knowledge of the nation and a regional economy at any time. In addition, with the adjustment of economic structure, its major setting and course setting should also keep pace with the social needs and build a bridge with industry standards by taking measures to make timely adjustment. However, at present, vocational colleges of our country are insufficient in conducting investigation and researches of market and enterprise requirements and fail to take comprehensive consideration, so that an apparent lag exists when setting their major courses.

\section{B. Teaching Content Is Lack of Specificity.}

Continuing education belongs to post-education, which is, the education is oriented to the on-the-job personnel and recognizes them as education accepters, and continuing education is the continuation and supplement of other forms of education. Usually, company worker who accept continuing education have a rich practical experience in the first production line, and most of them go back to the classroom with realistic problems encountered in their practical work, and they are keen to effectively solve the problems in real work through learning, as well as expect to be familiar with and grasp the latest technology, processes and methods related to the industry. As a matter of fact, at present, it is quite common that adult education in our country usually take higher education which is in equivalent level as an example for reference in teaching process and result of education evaluation system. Therefore, the blindness of this education teaching method are lack of practical measures to deal with adult learning behavior characteristics and ignore the demands of education receivers, so that the current situation of vocational mismatch between supply and demand of adult education has been formed.

\section{Out-Dated Teaching Method and Single Teaching Means}

At present, the teaching form of concentration and relative concentration are mainly adopted in the continuing education. Besides, conservative and single teaching means which can only create a teacher-control class with extremely little interaction remain to be prominent in continuing education course teaching, so that it is still unable to get rid of the traditional model in which teachers always stand on the stage and the students listen to in the audience. Because of insufficient in front-line practical experience, answers given by teachers for students' problems are more divorced from reality with only hollow content, much abstract description, and little concrete analysis.

\section{Existing Continue Education Policies and Mechanisms}

At the present stage, there are two major contradictions left among enterprise, employees and further education institutions: one is the contradiction between demands for own survival of enterprises and staff and needs for new technology and new knowledge; the second is the contradiction between enterprise production operation arrangement and continuing education teaching. Solving the two prominent contradictions is the key for higher vocational colleges to the implementation of service enterprises and society. For achieving this, higher vocational colleges will be required to satisfy companies' needs by actively implementing multiple flexible way of continuing education and organization teaching modes such as integrating door-to-door education service, face-to-face education service and self-study, combining centralized teaching with high-tech remote education, as well as combining stipulating teaching plan with mobile teaching, etc. By carrying out those multivariate and flexible teaching methods, teaching goal will eventually be realized to satisfy the requirements coming from four parties of enterprises, employees, society and colleges. But in the present stage, there are many limitations in our country's policies on continuing education of higher vocational colleges to develop foreign education and enterprise education, which has restricted the development of continuing education in higher vocational colleges and also affected enterprise employees' mastery and acquirement of new knowledge, new technology and promotion in education degree to a certain extent.

\section{SUGGESTION ON CONTINUING EdUCATION OF Higher COLLEGES RECOMMENDATIONS FOR ENTERPRISES AND EMPLOYEES}

\section{A. Integration of Higher Vocational Education Goal and Enterprise Continuing Education Goal}

Higher vocational colleges should rely on their own advantages and take full consideration on the needs of the enterprises so as to set up majors close to the social needs and manifest their own characteristics. Through communication with the masses of small and medium-sized enterprises, the author discovers that the ultimate goal of enterprise human resources departments provide chances of continuing education for their employees is to satisfy enterprises' needs of skillful front-line talents in production, construction, service and management. Therefore, higher vocational colleges should consider the actual needs of enterprises to combine continuing education, reform of enterprises and improvement of operation and management level when making arrangement of class content and hours, further introduction and absorption of advanced technology, further provide more education support for the development of training talents. At the same time, colleges should attach importance to the cultivation of educatees' practice ability and ability of combining theory and practice in order to better adapt to the needs of developing new technology and eventually to achieve the objective and requirements of enterprise employees training. 


\section{B. Establishing University-enterprise Cooperation and Coordination Mechanism and Adapting to the Enterprise Needs}

Enterprises' requirements in post skills, colleges' major setting and organization and implementation of curriculum system should be effectively combined. In Universityenterprise cooperation, efforts must be taken to explore diversified forms of implementation of personnel training and enable enterprises to participate in the teaching, management and decision making of colleges. For example, they should adapt to the regional economic demand and set schoolenterprise cooperation majors to enable students to fully be involved in the whole working process of enterprises and enterprises' cultural environment, and all graduates in that major (department) can become prospective employees of some enterprises. Continuing education training for staff on active duty is supposed to be completely in accordance with the requirements of enterprises. In a word, it should take the work of improving the students' professional ability, professional ethics and sustainable development ability as the starting point and consider enterprise production activities and ability of analyzing professional post as the foundation to drive development of curriculum system through cooperation of higher vocational colleges and enterprises according to the professional ability standard formulated by the industry and on the basis of national professional qualification certificate system; In addition, the former mode of curriculum development centered by discipline should be changed so as to enable curriculum content to be absorbed at any time and able to reflect the development and changes of professional technology, work and skills. Besides, it should make timely adjustments and updating, and also construction of practical and forward-looking courses should be attached attention to.

\section{Training Customized Talents for Enterprises}

The personnel training mode of combining college admissions, recruitment and internal staff training is supposed to be adopted, which is so-called order-form talent-training model. The main characteristics of this kind of training mode lie in that colleges and enterprises jointly formulate talents cultivating scheme so that colleges' teaching plans closely combine with enterprise human resources' training plan. After students completing their foundation courses and core professional courses, two elective courses are added in the last two semesters in accordance with the technical requirements come up with by enterprises and requirements for posts students are engaged in, and student can take these courses according to personal circumstances, so that customized talents training goal can be ultimately achieved by enterprises. There are two ways to this cultivating talent mode: one kind is offjob training at school; the other is a kind of correspondence education by concurrently studying and working.

\section{Scientific Problem Settlement Serving Enterprises}

Enterprises are not only required to sustainably organize their staff to gain knew knowledge and new methods, but supposed to train professional and technical talents in severe shortage so as to meet the needs of practical work and cope with the increasingly fierce market competition. Science and technology researches and new technology transfer are almost all undertaken by research institutions and ordinary institutions of higher learning and research universities, and the significant role of vocational continuing education in assisting enterprise to solve major technical research projects and renovating projects is often ignored. The institutions of higher education, as those who have the most intimate relations with the enterprise, the continuing education of higher vocational colleges should exert their own advantages and directly provide services for the enterprise production management and research and development of technology so as to accelerate the transformation of science and technology and become the propellant of enterprises in technology research and industry development in the true sense.

\section{E. Utilizing New Technology to Build a Modern Teaching Platform}

With the increasing progresses achieved in modern information technology, the methods of conducting continuing education should adapt to the demands of development in the time and accomplish the modernization of teaching methods. If there are qualified conditions, various tools such as special purpose televisions, videos, VCD with teaching materials and computer-assisted instruction software, etc. are applicable for the teaching of continuing education, and we can also conduct online instruction on network distance education system. Furthermore, when higher vocational colleges carry out continuing education jointly cooperating with enterprises, they can establish their own online instruction platform relying on campus network and further conduct networked teaching on eligible basic courses, so that it can effectively improve teaching quality, reduce costs and increase efficiency of running colleges.

\section{CONCLUSION}

Modern continuing education has been correlative and supplementary with vocational education since its birth, and higher vocational and technical colleges, as bases for cultivating professional, technical and practical talents who can make contributions to society and enterprises, not only are supposed to conduct off-job vocational and technical education but should hold all sorts of continuing education and professional skill trainings. Meanwhile, colleges can form their special competitive advantages of sustainable development only when they bravely face up with severely impair of homogenization tendency occurring in continuing education and according to special requirements of regional economic development, to determine a strategy for characteristic development.

\section{REFERENCES}

[1] Ma Longhai, Tang Yaoping, Song Qilin. The Problems and Countermeasures of current development of Higher Vocational College. Liaoning education research 2003-10-26 Journal.

[2] Liu Huijian. Insisiting on the scientific development outlook and developing the Higher Vocational Education vigorously - The Eight Problems and Countermeasures of current development of Higher Vocational Education. Higher Vocational Education (Journal of Tianjin Vocational Institute) 2004/05. 
[3] Lv Lining. A Tentative study on the current situation and existing problems of continuing education in Higher Vocational Colleges and its development countermeasures. Trade Union Forum (Journal of Shandong Management University) 2009/05. 